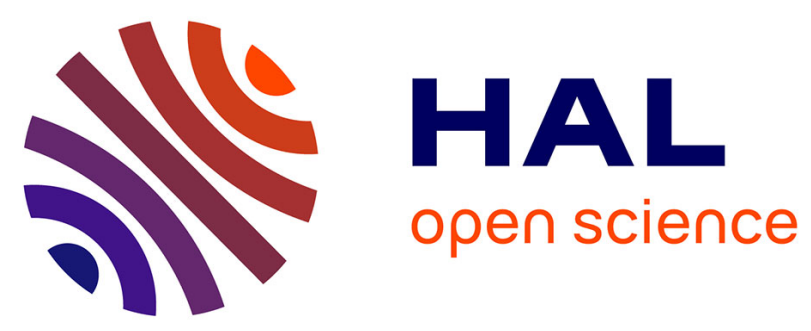

\title{
From supramolecular to solid state chemistry: crystal engineering of luminescent materials by trapping molecular clusters in an aluminium-based host matrix
}

Clement Falaise, A Ivanov, Yann Molard, Maria Amela-Cortés, Michael A. Shestopalov, Mohamed Haouas, Emmanuel Cadot, Stéphane Cordier

\section{To cite this version:}

Clement Falaise, A Ivanov, Yann Molard, Maria Amela-Cortés, Michael A. Shestopalov, et al.. From supramolecular to solid state chemistry: crystal engineering of luminescent materials by trapping molecular clusters in an aluminium-based host matrix. Materials Horizons, 2020, 7 (9), pp.2399-2406. 10.1039/d0mh00637h . hal-02948359

\section{HAL Id: hal-02948359 \\ https://hal.science/hal-02948359}

Submitted on 24 Sep 2020

HAL is a multi-disciplinary open access archive for the deposit and dissemination of scientific research documents, whether they are published or not. The documents may come from teaching and research institutions in France or abroad, or from public or private research centers.
L'archive ouverte pluridisciplinaire HAL, est destinée au dépôt et à la diffusion de documents scientifiques de niveau recherche, publiés ou non, émanant des établissements d'enseignement et de recherche français ou étrangers, des laboratoires publics ou privés. 


\section{From Supramolecular to Solid State Chemistry: Crystal Engineering of Luminescent Materials by Trapping Molecular Clusters in an Aluminium-based Host Matrix}

\author{
Haouas, ${ }^{a}$ Emmanuel Cadot ${ }^{a}$ and Stéphane Cordier* ${ }^{\mathrm{c}}$ \\ a. Institut Lavoisier de Versailles, UMR 8180 CNRS, UVSQ, Université Paris-Saclay, \\ Versailles, France. \\ b. Nikolaev Institute of Inorganic Chemistry SB RAS, Novosibirsk, 630090, Russia. \\ c. Univ Rennes, CNRS, ISCR - UMR 6226, ScanMAT - UMS 2001, F-35000 Rennes, \\ France
}

Clément Falaise, ${ }^{* a}$ Anton A. Ivanov, ${ }^{\mathrm{a}, \mathrm{b}}$ Yann Molard, ${ }^{\mathrm{c}}$ Maria Amela Cortes, ${ }^{\mathrm{c}}$ Michael A. Shestopalov, ${ }^{\mathrm{b}}$ Mohamed
Programming the supramolecular association of well-defined metal-based inorganic aggregates of different natures is an innovative concept to design materials. The emergence of such strategy requires to master i) the handling of metallic aggregates in solution and ii) the control of dynamic and subtle interactions (hydrogen bonding, electrostatic, van der Walls forces) at the nanoscopic scale. Herein, we report an appealing procedure, where $\boldsymbol{\gamma}$-cyclodextrin (CD) is used as host-guest stabilizing agent and structural linker, to organize luminescent molybdenum clusters $\left[\mathrm{Mo}_{6} \mathrm{X}_{8}^{\mathrm{i}} \mathrm{Cl}_{6}^{\mathrm{a}}\right]^{2-}(\mathrm{X}=\mathrm{Br}$ and $\mathrm{I})$ within well-ordered structures obtained from aqueous solutions. Such an approach enables to integrate highly luminescent $\left[\mathrm{Mo}_{6}{ }_{6}{ }_{8} \mathrm{Cl}_{6}^{\mathrm{a}}\right]^{2-}$ clusters within inert supramolecular architectures built-up from $\mathrm{CD}$ and aluminium oxo-hydroxo-aquo-clusters $\left[\mathrm{Al}_{13} \mathrm{O}_{4}(\mathrm{OH})_{24}\left(\mathrm{H}_{2} \mathrm{O}\right)_{12}\right]^{7+}$ (noted $\left\{\mathrm{Al}_{13}\right\}^{7+}$ ) which is optically silent in the absorption and emission spectral range. The charge is counter balanced by five $\mathrm{Cl}^{-}$anions. Interactions between clusters, $\mathrm{CD}$ and $\mathrm{Cl}^{-}$on one hand and interactions between polycations and $\mathrm{Cl}^{-}$on the other hand, lead to pseudo super-tetrahedrons $\left\{\left[\mathrm{Mo}_{6} I_{8}^{\mathrm{i}} \mathrm{Cl}_{6}^{\mathrm{a}}\right] @ 2 \mathrm{CD}_{6} \mathrm{Cl}_{4}\right.$ and $\left\{\mathrm{Al}_{13}\right\} \mathrm{Cl}_{4}$ respectively that share apices. It results in an open framework whose structure is related to that of lithium alumino silicate $\mathrm{LiAlSiO}_{4}$ (aka $\beta$-eucryptite). Compared to usual cluster based compounds where counter cations are alkalis or ammonium derivatives, in $\left\{\mathrm{Al}_{13}\right\}\left\{\mathrm{Mo}_{6} \mathrm{I}_{8}^{\mathrm{i}} \mathrm{Cl}_{6}^{\mathrm{a}}\right]$ @ @2 $\left.\mathrm{CD}\right\} \mathrm{Cl}_{5} \bullet 60 \mathrm{H}_{2} \mathrm{O}$, the number of clusters per unit cell volume dramatically decreases but their luminescence is not quenched. Indeed, the hybrid material shows excellent luminescent properties in the red-near infrared region with a quantum yield of $26 \%$.

\section{Introduction}

Atomically precise aggregates of metallic atoms represent an extensive library of building blocks to design materials due to their amazing structural diversity, chemical composition and functionality. ${ }^{1-5}$ Self-assembling at least two different inorganic modules within a well-defined 3D organization similarly as atoms in solid-state oxides, offers infinite perspectives in the field of crystal engineering and more

\section{New concepts}

The solid state chemistry enables to play with metal atoms generating packings of polyhedrons each based on central metal ions and a coordination sphere of ligands (e.g. O, chalcogens, halogens...). Instead of metal atoms, we pioneer a novel concept to design functional materials using preformed metal aggregates acting as complementary building blocks. Their programmed association within a 3D organization is insured by a natural, non-toxic and cheap supramolecular linker $(\gamma$ cyclodextrin), and the resulting arrangement mimics the crystal edifices found in oxide solid-state chemistry. Following the idea developed in solid state oxide chemistry to trap luminophores in an inert matrix, we show herein how highly luminescent metal clusters can be integrated in an inert hybrid matrix involving cyclodextrin moieties and aluminium based polycations to form a tailor-made architecture related to that of the lithium alumina silicate $\mathrm{LiAlSiO}_{4}$.

Taking benefit of the extensive library of soluble metallic aggregates, cyclodextrin driven self-assembling concept offers important perspectives in the field of crystal engineering and more generally in material science. Indeed, considering the design of a material with several desired properties (optical, catalytic, magnetic...), building blocks that will carry those specific properties could be selected among numerous types of soluble metallic aggregates such as transition metal atom clusters, polyoxometalates, $\mathrm{Al}^{3+}$ based polycations, polynuclear single molecule magnets $\left(\mathrm{Mn}_{12}, \mathrm{Fe}_{8} ..\right)$ or polynuclear $\mathrm{d}^{10}$ complexes. 
generally in material science. ${ }^{6-8}$ The recent discovery of CLUSPOM materials ${ }^{9}$ involving the association through cyclodextrin moieties of metal atom clusters (CLUS) and polyoxometalates (POM) - two antagonist but complementary metal aggregates based building blocks - offers important perspectives in the field of crystal engineering and more generally in material science. Indeed, considering the design of a target material with several building blocks that will carry specific properties (optic, catalytic, magnetic, etc.) could be selected among the vast library of soluble metallic aggregates found in the literature. Then, the self-assembling of building blocks to form the target material will be driven by a supramolecular organic linker, such as cyclodextrins as demonstrated earlier in CLUSPOM compounds. ${ }^{9}$ Many metallic aggregates are potential candidates as structuring and functional building blocks. In addition to transition metal atom clusters and POMs, one can cite: $\mathrm{M}^{4+}$ and $\mathrm{Ln}^{3+}$ oxo-clusters, aluminium polycations, single molecule magnet $\left(\mathrm{Mn}_{12,}, \mathrm{Fe}_{8}\right.$, $\mathrm{Co}_{\mathrm{x}}$ ), polynuclear $\mathrm{d}^{10}$ complexes. ${ }^{10-14}$

Concepts must be now developed for the rational design of functional materials based on this original supramolecular strategy to meet the current challenges of chemists. One of them aims at creating new materials with molecular building blocks of different natures that could mimick the crystal chemistry and some properties of solid state compounds. The solid-state chemistry enables to play with metal atoms generating packings of polyhedrons each based on central metal ions and a coordination sphere of ligands (e.g. O, chalcogens, halogens, etc.). Instead of metal atoms, we pioneer a novel concept to design functional materials using preformed metal aggregates acting as complementary building blocks. As an illustration, the solid-state chemistry of oxides has yield materials with a tremendous range of physical properties in particular luminescent oxides doped with rare earth. ${ }^{15}$ As luminophores, $\left\{\mathrm{Mo}_{6}\right\}$ clusters are ones of the best inorganic luminescent dyes. However, there is hitherto no chemical route to dope solid-state oxides by $\mathrm{Mo}_{6}$ clusters. This prevents the development of applications (e.g. scintillating crystals, lasers, photocatalysts) ${ }^{16-18}$ in fields requiring the design of a crystalline material based on a host matrix with a well-defined structure (aluminates, ${ }^{15,19-22}$ silicates, $^{23-25}$ alumino-silicates ${ }^{26-29}$ ). In this work, following the idea developed in solid-state oxide chemistry to trap luminophores in an inert matrix, we show how a highly luminescent metal cluster functional building blocks can be integrated in an inert hybrid matrix involving cyclodextrin moieties and transparent $\left[\mathrm{Al}_{13} \mathrm{O}_{4}(\mathrm{OH})_{24}\left(\mathrm{H}_{2} \mathrm{O}\right)_{12}\right]^{7+}$ polycations.

Octahedral molybdenum cluster units $\left[\mathrm{Mo}_{6} \mathrm{X}_{8}^{\mathrm{i}} \mathrm{X}_{6}^{\mathrm{a}}\right]^{\mathrm{n}}\left(\mathrm{X}^{\mathrm{i}}=\right.$ inner ligand; $X^{a}=$ apical ligand) constitute versatile building blocks for the elaboration of hybrid nano-materials ${ }^{30-35}$ and functional surfaces ${ }^{36,37}$. In particular, they i) absorb light continuously from UV to visible, ii) emit continuously from red to NIR region through several excited emissive states, iii) are able to photoinduce singlet oxygen generation, iv) exhibit interesting catalytic and photo-catalytic properties. First, an inorganic precursor is prepared by solid-state chemistry and then the resulting cluster unit is chemically modified or paired with counter cations to be integrated in the matrix, generating amorphous or poorly-crystalline materials in which the spacing between clusters is mostly uncontrolled, ${ }^{30,35,38-44}$ except in liquid crystals ${ }^{32,33,45,46}$ containing clusters. On the other hand, well-crystalline coordination polymers built from hexamolybdenum cluster based lead to poorly luminescent compounds. ${ }^{47,48}$

As an alternative route, we propose to design luminescent crystalline compounds using programmatic association of octahedral molybdenum clusters directed by $\gamma$-cyclodextrin (CD) which is a water-soluble, natural, non-toxic and cheap macrocyclic linker. The $y$-cyclodextrin is a flexible macrocyclic oligosaccharide built from eight glucopyranose units defining inner cavity of $11 \AA$. We and others already demonstrated that $C D$ can bind and organize the inorganic aggregates at the nanoscale. ${ }^{9,49-56}$

Among all the octahedral molybdenum halide clusters, $\left[\mathrm{Mo}_{6} \mathrm{I}_{8}^{\mathrm{i}} \mathrm{Cl}_{6}^{\mathrm{a}}\right]^{2-}$ exhibits the best phosphorescent performances in terms of quantum yield (57\%) and lifetime (300 $\mu \mathrm{s})$ in deaerated $\mathrm{CH}_{3} \mathrm{CN}{ }^{57}$ The manipulation of cluster with apical chlorine is highly challenging in aqueous solution due to the substitution of $\mathrm{Cl}^{-}$by $\mathrm{H}_{2} \mathrm{O}$ or $\mathrm{OH}^{-}$groups leading to precipitation of neutral clusters and a collapsing of the luminescent properties. ${ }^{58}$ Herein we tackle this issue by using $\gamma$-cyclodextrin as protecting shell of hydrolytically fragile $\left[\mathrm{Mo}_{6} \mathrm{I}_{8}^{\mathrm{i}} \mathrm{Cl}_{6}^{\mathrm{a}}\right]^{2-}$ cluster. We demonstrate this strategy can be also employed to manipulate $\left[\mathrm{Mo}_{6} \mathrm{Br}_{8}^{\mathrm{i}} \mathrm{Cl}_{6}^{\mathrm{a}}{ }_{6}\right]^{2-}$ in water. Interestingly $\mathrm{CD}$ binds strongly octahedral clusters resulting in the formation of supramolecular adducts $\left\{\left[\mathrm{Mo}_{6} \mathrm{X}_{8}^{\mathrm{i}} \mathrm{Cl}_{6}^{\mathrm{a}}\right] @ 2 \mathrm{CD}\right\}^{2-}$ with $\mathrm{X}=\mathrm{Br}$ and $\mathrm{I}$, which adopt distinctive host-guest conformation in solution depending on the inner ligand. Then, we show that the resulting host-guest complexes can be associated together in different ways, offering various degree of dilution of luminophores. Finally, we prepared red/nearinfrared luminescent supramolecular architectures built from $\left\{\left[\mathrm{Mo}_{6} \mathrm{X}_{8}^{\mathrm{i}} \mathrm{Cl}_{6}^{\mathrm{a}}{ }_{6} @ 2 \mathrm{CD}\right\}^{2-}\right.$ and preformed aluminium polycation $\left[\mathrm{Al}_{13} \mathrm{O}_{4}(\mathrm{OH})_{24}\left(\mathrm{H}_{2} \mathrm{O}\right)_{12}\right]^{7+}$ (noted $\left\{\mathrm{Al}_{13}\right\}^{7+}$ ).

\section{Results and discussion}

Hydrolysis of the water-soluble $\left[\mathrm{Mo}_{6} \mathrm{X}_{8}^{\mathrm{i}} \mathrm{Cl}_{6}^{\mathrm{a}}\right]^{2-}$ salts with $\mathrm{X}^{\mathrm{i}}=\mathrm{Cl}$, $\mathrm{Br}$ or $\mathrm{I}$ in aqueous solution leads to a rapid precipitation of aqua-cluster complexes. ${ }^{58,59}$ However we observe that the presence of $\gamma$-cyclodextrin ( 2 equiv. of $C D$ per clusters) in aqueous solution avoids the formation of solids, expect for $\left[\mathrm{Mo}_{6} \mathrm{Cl}_{8}^{\mathrm{i}} \mathrm{Cl}_{6}^{\mathrm{a}}\right]^{2-}$ that is the smallest cluster and the less luminescent of the $\left[\mathrm{Mo}_{6} \mathrm{X}_{8}^{\mathrm{i}} \mathrm{Cl}_{6}^{\mathrm{a}}\right]^{2-}$ series. It must be worth noting that the replacement of $\gamma$-cyclodextrin by other cyclodextrins having smaller cavity size ( $\alpha$ - or $\beta$-cyclodextrin) always leads to aqua-cluster complexes precipitation. From these observations, we hypothesized that $\gamma$-cyclodextrin stops or at least slows down the hydrolytic attacks of $\left[\mathrm{Mo}_{6} \mathrm{X}_{8}^{\mathrm{i}} \mathrm{Cl}_{6}^{\mathrm{a}}\right]^{2-}$. Previous studies demonstrated the host-guest encapsulation is an appealing route to trap and stabilize a myriad of fleeting species in aqueous solution. ${ }^{60-65}$ In general this stabilization is efficient when the guest entity matches the host cavity, as observed herein between $\left[\mathrm{Mo}_{6} \mathrm{x}_{8}^{\mathrm{i}} \mathrm{Cl}_{6}^{\mathrm{a}}\right]^{2-}$ and $\mathrm{y}$-cyclodextrin. 


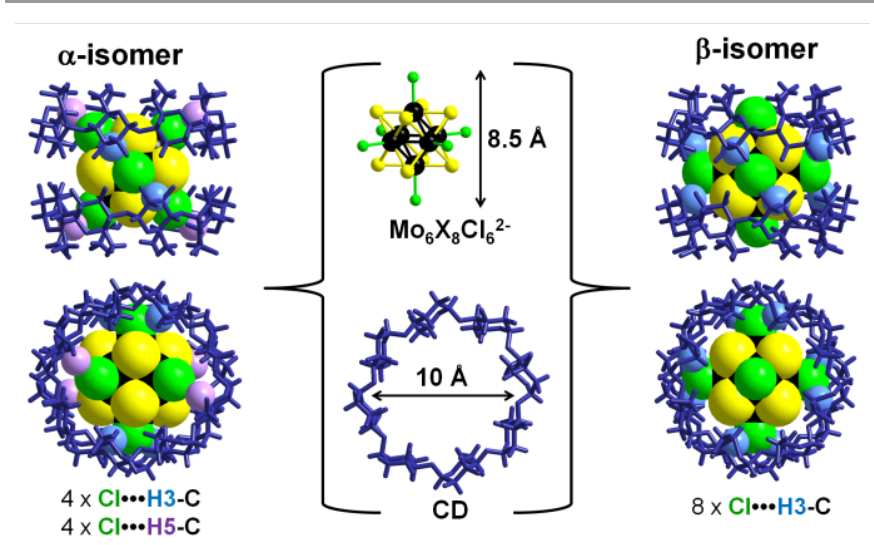

Figure 1: Illustration of the host-guest isomers ( $\alpha$ and $\beta$ ) built from the close embedment of $\left[\mathrm{Mo}_{6} \mathrm{X}_{8}^{i} \mathrm{Cl}_{6}{ }_{6}\right]^{2-}$ within two CDs. $\alpha$ - and $\beta$ - isomers differ from a $45^{\circ}$ rotation of cluster. Top and sideviews of $\left\{\left[\mathrm{Mo}_{6} \mathrm{X}_{8}{ }_{8} \mathrm{Cl}_{6}{ }_{6}\right]^{2-} @ 2 \mathrm{CD}\right\}^{2-}$ highlight close interactions between inner protons of $\mathrm{CD}$ and the apical ligand of the guest $(\mathrm{Cl})$. Color code: black $=\mathrm{Mo}$, yellow $=\mathrm{X}(\mathrm{Br}$ or $\mathrm{I})$, green $=\mathrm{Cl}$. $\mathrm{H} 3$ and $\mathrm{H} 5$ involved in close host-guest interactions are in blue and pink, respectively.

To gain further insight on this stabilization process, crystallization attempts have been successfully conducted, revealing the formation of different supramolecular host-guest isomers (Fig. 1). Different crystalline products have grown by evaporation of aqueous mixtures containing different CD:cluster ratio, nevertheless all are composed of one cluster deeply embedded into two tori hosts facing their secondary rim (Fig. 1). The structural analysis of isostructural compounds $\mathrm{Na}_{2}\left\{\left[\mathrm{Mo}_{6} \mathrm{X}_{8}^{\mathrm{i}} \mathrm{Cl}_{6}^{\mathrm{a}}\right] @ 2 \mathrm{CD}\right\} \cdot 3 \mathrm{NaCl} \cdot 10 \mathrm{H}_{2} \mathrm{O}(\mathrm{X}=\mathrm{Br}$ or I, noted $1-\mathrm{Br}$ and 1-I), obtained with $C D$ :Cluster $=2: 1$, reveals the presence of host-guest $\alpha$-isomer $\left\{\left[\mathrm{Mo}_{6} \mathrm{X}_{8}^{\mathrm{i}} \mathrm{Cl}_{6}^{\mathrm{a}}\right] @ 2 \mathrm{CD}\right\}^{2-}$ (Fig. 1). ${ }^{66}$ In this inclusion complex, the plane of $\left[\mathrm{Mo}_{6} \mathrm{X}_{8}^{\mathrm{i}} \mathrm{Cl}_{6}^{\mathrm{a}}\right]^{2-}$ lined by four equatorial chlorine atoms is perpendicularly directed to $C D$ faces while the remaining chlorine atoms point between the secondary rims of the tori host. In such arrangement, all apical chlorines are involved in short contacts with $C D$ inwarddirected hydrogen, contributing to the stability of supramolecular aggregates. The chlorines located between $\mathrm{CDs}$ form four weak intermolecular interactions with $\mathrm{H} 3$ $\left(\mathrm{Cl}^{\mathrm{a}} \bullet \bullet \mathrm{H}-\mathrm{C}=2.7-2.8 \AA\right)$ and the four remaining engulfed chlorines give close contacts with $\mathrm{H} 5\left(\mathrm{Cl}^{\mathrm{a}} \bullet \bullet \cdot \mathrm{H}-\mathrm{C}=2.7-2.9 \AA\right)$. In addition, inner ligands of the bulkiest cluster also participate to the supramolecular cohesion of 1-I, giving contacts between iodide atoms and the inner protons $\left(I^{i} \bullet \bullet H-C=3.1-3.3 \AA\right)$. Interestingly, compounds $\mathrm{Na}_{2}\left\{\left[\mathrm{Mo}_{6} \mathrm{X}_{8}^{\mathrm{i}} \mathrm{Cl}_{6}^{\mathrm{a}}\right] @ 2 \mathrm{CD}\right\} \bullet \mathrm{CD} \bullet 45 \mathrm{H}_{2} \mathrm{O}$ (noted $2-\mathrm{Br}$ and $2-1$ ) obtained with $\mathrm{CD}$ :Cluster=3:1, crystallize in the same lattice (1422) however they exhibit two different isomers. ${ }^{67}$ The $\alpha$-isomer is still observed for $\left[\mathrm{Mo}_{6}{ }_{8}{ }_{8} \mathrm{Cl}_{6}^{\mathrm{a}}\right]^{2-}$ (Fig. S4), while the bromine derivative adopts another host-guest arrangement ( $\beta$-isomer; Fig. 1, S). The difference between $\alpha$ and $\beta$-isomers consists in $45^{\circ}$ rotation of cluster embedded within pocket delimited by two $C D s$. In $\beta$-isomer, one $C_{4}$ axis of $\left[\mathrm{Mo}_{6} \mathrm{Br}_{8}^{\mathrm{i}} \mathrm{Cl}_{6}^{\mathrm{a}}\right]^{2-}$ is aligned with the $\mathrm{C}_{8}$ axis of the host Consequently four chlorine atoms are involved in short contact with $\mathrm{H} 3\left(\mathrm{Cl}^{\mathrm{a}} \bullet \bullet \mathrm{H}-\mathrm{C}=2.7-2.9 \AA\right)$, whereas the two remaining chlorines point on the center of the $C D$ without interaction with the host. Clearly, $\left\{\left[\left.\mathrm{Mo}_{6}\right|_{8} ^{\mathrm{i}} \mathrm{Cl}_{6}^{\mathrm{a}}{ }_{6} @ 2 \mathrm{CD}\right\}^{2-}\right.$ adopts exclusively $\alpha$ - conformation due to an optimization of attractive dispersion forces involving both inner and apical ligands of bulky guest. Oppositely, only the apical ligands of $\left[\mathrm{Mo}_{6} \mathrm{Br}_{8}^{\mathrm{i}} \mathrm{Cl}_{6}^{\mathrm{a}}\right]^{2-}$ are implicated in host-guest interactions, resulting in a rotational degree of freedom, highlighted by the formation of $\alpha$ - or $\beta$-isomer depending on the minimization of lattice energy in the solid. As commonly observed on crystal structures involving $C D$, the crystal packing of all these compounds (Fig S6-S7) consist in tubular arrangements resulting from inclusion complexes interconnected through the primary rims of $C D(O \bullet \bullet O=2.7-3.0 \AA) .{ }^{9,50,52-54,68}$ These structural organizations generate voids ( 15 and $45 \%$ of the unit cell volume for $\mathbf{1}$ and 2, respectively; Fig S6-S9) where water molecules and counter-cations are located. In both compounds containing $\mathrm{CD}$, the shortest distance between the gravity centers of two clusters is slightly bigger than in the compounds $\mathrm{TBA}_{2}\left[\mathrm{Mo}_{6} \mathrm{X}_{8}^{\mathrm{i}} \mathrm{Cl}_{6}^{\mathrm{a}}\right.$ ] with $\mathrm{X}=\mathrm{Br}^{69}$ or $\mathrm{I}^{70}$ (15.9 vs 12.8 $\AA$ )), avoiding intercluster partial quenching phenomena.

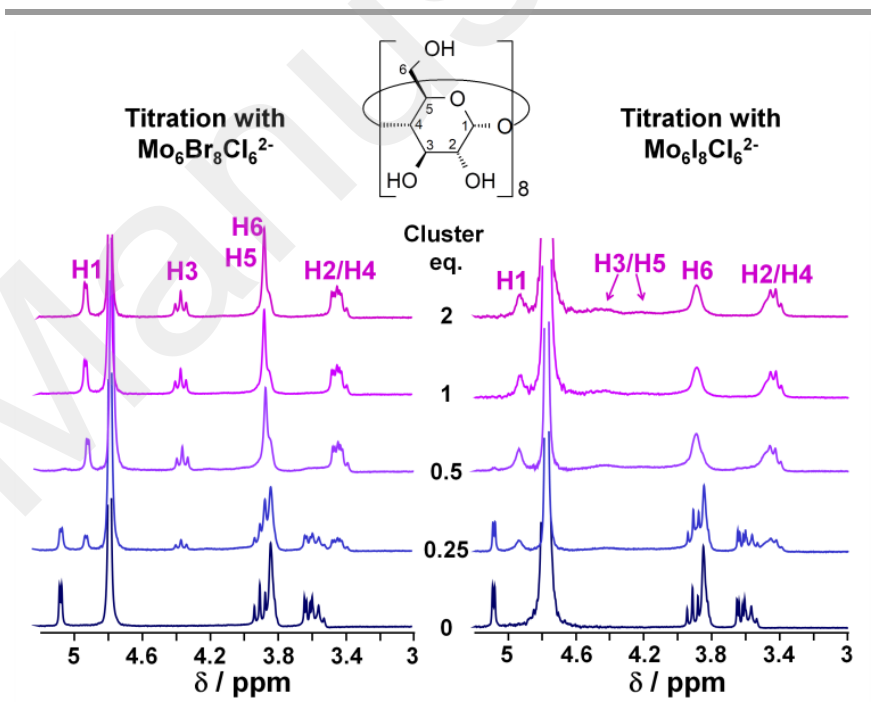

Figure 2: ${ }^{1} \mathrm{H}$ NMR spectra resulting of the titration of $2 \mathrm{mM}$ aqueous solution of $\gamma-\mathrm{CD}$ by $\left[\mathrm{Mo}_{6} \mathrm{X}_{8}^{\mathrm{i}} \mathrm{Cl}_{6}^{\mathrm{a}}\right]^{2-}$ clusters with $\mathrm{X}=\mathrm{Br}$ (left) or I (right), showing the influence of inner ligand on the host-guest conformation ( $\beta$-isomer for $\mathrm{X}=\mathrm{Br}$ and $\alpha$-isomer for $\mathrm{X}=\mathrm{I}$ ).

Supramolecular host-guest interactions in aqueous solution have been studied by ${ }^{1} \mathrm{H}-\mathrm{NMR}$ experiments, highlighting that the host-guest conformation ( $\alpha$ - or $\beta$-isomer) is dictated by the cluster core nature (Fig. 2). In fact, ${ }^{1} \mathrm{H}$ NMR signals of $\mathrm{CD}$ in presence of $\left[\mathrm{Mo}_{6} \mathrm{Br}_{8}^{i} \mathrm{Cl}_{6}^{\mathrm{a}}\right]^{2-}$ reveal a strong shift of $\mathrm{H} 3$, corresponding to fingerprint of $\beta$-isomer arrangement. Oppositely, the inclusion complex built from $\left[\mathrm{Mo}_{6} \mathrm{I}_{8}^{\mathrm{i}} \mathrm{Cl}_{6}^{\mathrm{a}}\right]^{2-}$ espouses the $\alpha$-isomer arrangement as characterized by ${ }^{1} \mathrm{H}$ NMR shift and broadening of $\mathrm{H} 3$ and H5. Importantly, ${ }^{1} \mathrm{H}-\mathrm{NMR}$ titration experiments (Fig. 2, S11-14) evidence that clusters and $C D$ are involved in non-labile 2:1 host-guest system typically observed when cyclodextrin pocket bind strongly molecular clusters. ${ }^{9,52,54}$ Previous reports demonstrated that origin of these associations is related to desolvation of guest (chaotropic effect) supported by the optimization of dispersion forces. ${ }^{54,71,72}$ It is worth noting that ESI-MS investigations (see supporting information; Fig S16 and S17) spotlight high host- 
guest stability constants of these supramolecular aggregates since they persist even in low concentration $(20 \mu \mathrm{M})$. Additionally, these ESI-MS results suggest that the host-guest stabilization is more efficient for the $\left[\mathrm{Mo}_{6} \mathrm{I}_{8}^{\mathrm{i}} \mathrm{Cl}_{6}^{\mathrm{a}}\right]^{2-}$ cluster since no hydrolytic product was detected (Fig S16) contrarily to the case with bromine derivative (Fig S17).

Thanks to the supramolecular stabilization of $\left[\mathrm{Mo}_{6} \mathrm{X}_{8}^{\mathrm{i}} \mathrm{Cl}_{6}^{\mathrm{a}}\right]^{2-}$, we investigated for the first time, the redox and optical properties of molybdenum halide clusters in aqueous solution. Under UV irradiation, the $\left\{\left[\mathrm{Mo}_{6} \mathrm{X}_{8}^{\mathrm{i}} \mathrm{Cl}_{6}^{\mathrm{a}}{ }_{6} @ 2 \mathrm{CD}\right\}^{2-}\right.$ inclusion complexes in deaerated water exhibit broad luminescence emission spectra in red/NIR region with maxima located at 715 and $690 \mathrm{~nm}$ for $\mathrm{Br}$ - and I-derivatives, respectively (Fig. 3, left). Investigations of electrochemical behaviour of $\left\{\left[\mathrm{Mo}_{6} \mathrm{I}_{8}^{\mathrm{i}} \mathrm{Cl}_{6}^{\mathrm{a}}{ }_{6}\right] @ 2 \mathrm{CD}\right\}^{2-}$ in aqueous solution $\left(25 \mathrm{mM} \mathrm{HClO}_{4}, 1\right.$ $\mathrm{mM}$ of cluster; Fig. S18-20), show $\left[\mathrm{Mo}_{6} \mathrm{I}_{8}^{\mathrm{i}} \mathrm{Cl}_{6}^{\mathrm{a}}\right]^{2-}$ based hostguest complex undergoes a quasi-reversible monoelectronic wave at $E_{1 / 2}=1 \mathrm{~V}$ vs SCE (Fig. 3, right), corresponding to the redox couple $\left[\mathrm{Mo}_{6} \mathrm{I}_{8}^{\mathrm{i}} \mathrm{Cl}_{6}^{\mathrm{a}}\right]^{-} /\left[\mathrm{Mo}_{6} \mathrm{I}_{8}^{\mathrm{i}} \mathrm{Cl}_{6}^{\mathrm{a}}\right]^{2-}$. The corresponding redox wave cannot be observed for the inclusion complex involving $\left[\mathrm{Mo}_{6} \mathrm{Br}_{8}^{\mathrm{i}} \mathrm{Cl}_{6}^{\mathrm{a}}\right]^{2-}$, suggesting a redox potential higher than that of the water oxidation in our conditions. This is supported by previous electrochemical studies in organic solvents, showing that the half-wave potential of the bromide derivative is about $+0.3 \mathrm{~V}$ higher than that observed for the iodide derivative. ${ }^{57,73}$
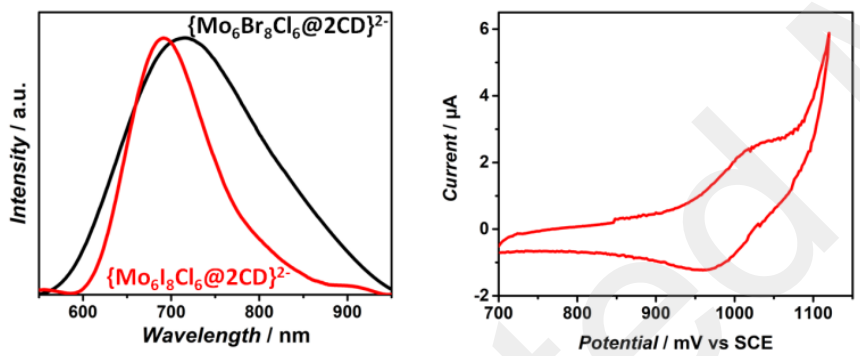

Figure 3: Left) Normalized emission spectra of inclusion complexes $\left\{\left[\mathrm{Mo}_{6} \mathrm{X}_{8}^{\mathrm{i}} \mathrm{Cl}_{6}^{\mathrm{a}}\right] @ 2 \mathrm{CD}\right\}^{2-}$ in deaerated aqueous solutions. Right) Cyclic voltammetry of $\left\{\left[\left.\mathrm{Mo}_{6}\right|_{8} ^{\mathrm{i}} \mathrm{Cl}_{6}^{\mathrm{a}}{ }_{6}\right] @ 2 \mathrm{CD}\right\}^{2-}(1 \mathrm{mM})$ in $25 \mathrm{mM} \mathrm{HClO}$ aqueous solution (working electrode = glassy carbon, reference electrode $=\mathrm{SCE}$, scan rate $=50 \mathrm{mV} / \mathrm{s}$ ).

The luminescent and redox-active supramolecular entities $\left\{\left[\mathrm{Mo}_{6} \mathrm{X}_{8}^{\mathrm{i}} \mathrm{Cl}_{6}^{\mathrm{a}}{ }_{6} @ 2 \mathrm{CD}\right\}^{2-}\right.$ are appealing earth-abundant elements based building blocks for the design of innovative materials exhibiting well-ordered structural arrangement. In solid-state oxides chemistry, the dilution of luminescent species in an inert oxide matrix, such as $\mathrm{Nd}^{3+}$ ions in yttrium aluminium garnet $\left(\mathrm{Y}_{3} \mathrm{Al}_{5} \mathrm{O}_{12}\right)$, corresponds to active component in solidstate lasers. ${ }^{74,75}$ Inspired by the common use of aluminium matrix as transparent host matrix, ${ }^{15}$ we decided to associate $\left\{\left[\mathrm{Mo}_{6} \mathrm{X}_{8}^{\mathrm{i}} \mathrm{Cl}{ }_{6}^{\mathrm{a}}\right] @ 2 \mathrm{CD}\right\}^{2-}$ with water-stable aluminium species. The most stable $\mathrm{Al}$ based polynuclear species in aqueous solution is the aluminium polycation $\left[\mathrm{Al}_{13} \mathrm{O}_{4}(\mathrm{OH})_{24}\left(\mathrm{H}_{2} \mathrm{O}\right)_{12}\right]^{7+}$ (noted $\left.\left\{\mathrm{Al}_{13}\right\}^{7+}\right) .^{4,76,77}$ The $\left\{\mathrm{Al}_{13}\right\}^{7+}$ unit adopts a $\varepsilon-$ Keggin type arrangement, composed of a central $\mathrm{AlO}_{4}$ polyhedron connected with twelve peripheral $\mathrm{AlO}_{6}$ polyhedra, and surrounded by aqua or hydroxo groups capable to act as hydrogen-bond donors. ${ }^{78}$ The $\left\{\mathrm{Al}_{13}\right\}^{7+}$ unit is also particularly attractive due to its positive charge and to its optical silence in the absorption and emission spectral range of molybdenum clusters. Moreover ${ }^{1} \mathrm{H}$ NMR investigations reveals that the presence of $\left\{\mathrm{Al}_{13}\right\}^{7+}$ unit does not influence the ${ }^{1} \mathrm{H}$ NMR signal of the CD (Fig. S15), meaning the aluminium polycations does not interact with inner cavity of $C D$. In the light of this observation it results that the polycations in aqueous solution should not affect the host-guest stabilization of $\left[\mathrm{Mo}_{6} \mathrm{X}_{8}^{\mathrm{i}} \mathrm{Cl}_{6}^{\mathrm{a}}\right]^{2-}$.

a)
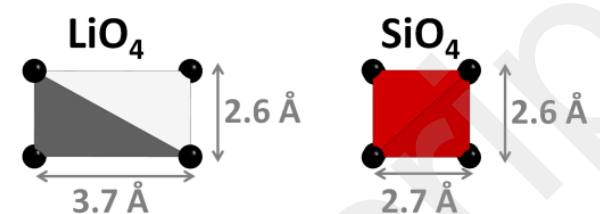

$2.7 \AA$

b)

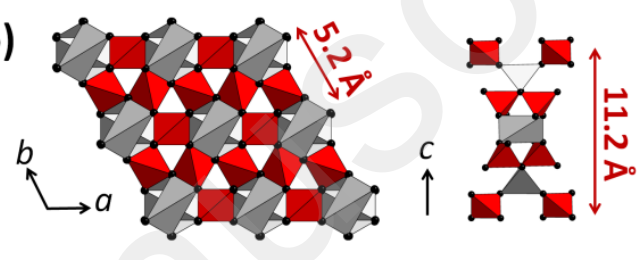

c)
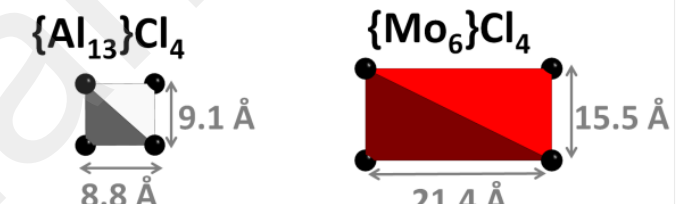

$21.4 \AA$

d)

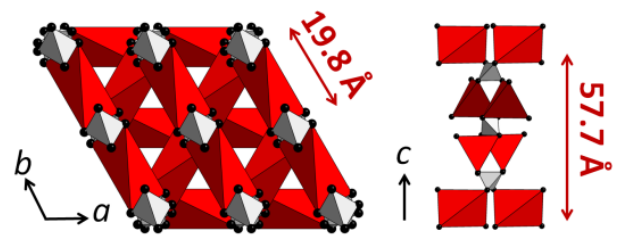

Figure 4: a) Illustration of $\mathrm{SiO}_{4}$ and $\mathrm{LiO}_{4}$ pseudo-tetrahedrons observed in the crystal structure of $\beta$-eucryptite. b) View of $\mathrm{SiO}_{4}$ and $\mathrm{LiO}_{4}$ polyhedrons in the structure type $\mathrm{LiAlSiO}_{4}$ showing that those building blocks are connected by their vertex. Color code: $\mathrm{LiO}_{4}$ are in grey and $\mathrm{SiO}_{4}$ are in red. c) Illustration of the pseudo super-tetrahedron $\left\{\mathrm{Al}_{13}\right\} \mathrm{Cl}_{4}$ and $\left\{\mathrm{Mo}_{6}\right\} \mathrm{Cl}_{4}$ which are drastically larger than the polyhedral observed in $\beta$ eucryptite. d) View of $\left\{\mathrm{Al}_{13}\right\} \mathrm{Cl}_{4}$ and $\left\{\mathrm{Mo}_{6}\right\} \mathrm{Cl}_{4}$ polyhedrons in the $\mathbf{3}-\mathrm{X}(\mathrm{X}=\mathrm{Br}$ or I) showing the strong analogy with $\beta$-eucryptite structure. Color code: $\left\{\mathrm{Al}_{13}\right\} \mathrm{Cl}_{4}$ are in grey and $\left\{\mathrm{Mo}_{6}\right\} \mathrm{Cl}_{4}$ are in red.

Compounds $\left\{\mathrm{Al}_{13}\right\}\left\{\left[\mathrm{Mo}_{6} \mathrm{X}_{8}^{\mathrm{i}} \mathrm{Cl}_{6}^{\mathrm{a}}\right] @ 2 \mathrm{CD}\right\} \mathrm{Cl}_{5} \bullet 60 \mathrm{H}_{2} \mathrm{O}$ with $\mathrm{X}=\mathrm{Br}$ or I (noted 3-Br and 3-I) are harvested from evaporated aqueous mixtures of $\left\{\mathrm{Al}_{13}\right\}^{7+}$ and $\left\{\left[\mathrm{Mo}_{6} \mathrm{X}_{8}^{\mathrm{i}} \mathrm{Cl}_{6}^{\mathrm{a}}{ }_{6} @ 2 \mathrm{CD}\right\}^{2-}\right.$ (1-Br or 1-I used as cluster precursors) in a 1:1 ratio, and crystallize in the same chiral lattice $\left(P 6_{2} 22\right)$ with intricate crystalline structure. ${ }^{79}$ It is worth pointing out that those structural arrangements are related to the structure-type $\mathrm{LiAlSiO}_{4}{ }^{80}$ also known as $\beta$ eucryptite, wherein $\mathrm{Li}, \mathrm{Al}, \mathrm{Si}$ cations and $\mathrm{O}$ are respectively located on 3a/3b (half occupancy), 3d, 3c and 12k Wyckoff positions. The building blocks are $\mathrm{LiO}_{4}, \mathrm{AlO}_{4}$ and $\mathrm{SiO}_{4}$ tetrahedrons that share their apices (Fig. $4 \mathrm{a}$ and $4 \mathrm{~b}$ ). It results in a non-porous extended structure. In 3-Br and 3-I, the $3 \mathrm{~d}$ site 
is empty whilst $\left\{\mathrm{Al}_{13}\right\}^{7+},\left\{\left[\mathrm{Mo}_{6} \mathrm{X}_{8}^{\mathrm{i}} \mathrm{Cl}_{6}^{\mathrm{a}}\right] @ 2 \mathrm{CD}\right\}^{2-}$ are located on $3 \mathrm{~b}$ and $3 \mathrm{c} . \mathrm{Cl}^{-}$ion is fully located at a $12 \mathrm{k}$ position. This arrangement leads to pseudo super-tetrahedrons $\left\{\left[\mathrm{Mo}_{6} \mathrm{X}_{8}^{\mathrm{i}} \mathrm{Cl}_{6}^{\mathrm{a}}\right] @ 2 \mathrm{CD}\right\} \mathrm{Cl}_{4}$ (noted $\left\{\mathrm{Mo}_{6}\right\} \mathrm{Cl}_{4}$ ) and $\left\{\mathrm{Al}_{13}\right\} \mathrm{Cl}_{4}$ respectively that share apices (Fig. $4 \mathrm{c}$ and $4 \mathrm{~d}$ ). In brief, the $\left\{\mathrm{Al}_{13}\right\} \mathrm{Cl}_{4}$ is almost a perfect polyhedron defined by four chlorine atoms capping the $\left\{\mathrm{A}_{\mid 13}\right\}$ unit (Fig. S1). Oppositely, $\left\{\mathrm{Mo}_{6}\right\} \mathrm{Cl}_{4}$ super-tetrahedrons exhibit large distortions compared to a $\mathrm{LiO}_{4}$ motif in $\beta$-eucryptite (Fig. S2). Owing to these pseudo super-tetrahedrons, the resulting architecture exhibits large voids estimated at $41 \%$ of the unit cell. In order to counter balance the positive charge, a disordered $\mathrm{Cl}^{-}$is distributed in the voids. The use of super-tetrahedrons for the description of these highly porous structures reminds the work of Férey and coworkers for the description of unrivalled MIL100 and MIL-101. ${ }^{81,82}$ We hypothesize that other topologies could be achieved using other soluble metallic aggregates. a)

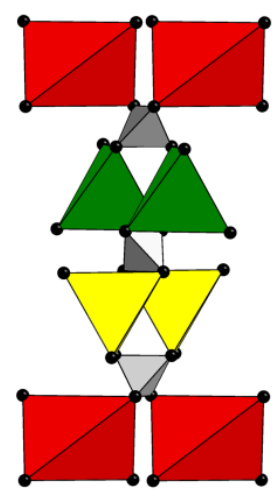

b)

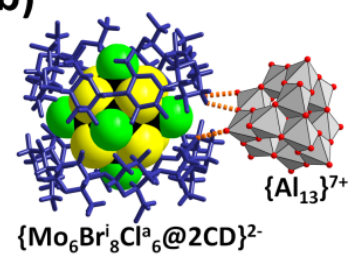

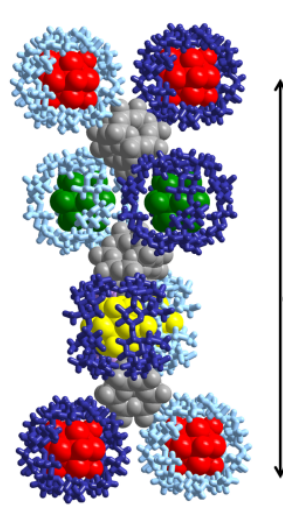

$57.7 \AA ̊$

c)

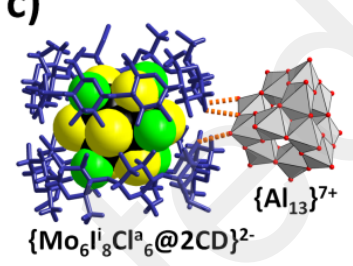

Figure 5: a) View of the half helical turn of the double helix arrangement defined by $\left\{\left[\mathrm{Mo}_{6} \mathrm{X}_{8}^{\mathrm{i}} \mathrm{Cl}_{6}^{\mathrm{a}}\right] @ 2 \mathrm{CD}\right\}^{2-}$ adducts which are structured through $\left\{\mathrm{Al}_{13}\right\}^{7+}$ packed along the $c$ axis. b) and c) Illustration of the hydrogen bonds (dotted orange lines) between one $\left\{\mathrm{Al}_{13}\right\}^{7+}$ and one host-guest complex. Different host-guest conformations are adopted depending of the nature of inner ligands, i.e. $\beta$-form for $X=B r$ and $\alpha$-form for $X=I$.

The structural arrangement of $\mathbf{3}-\mathbf{B r}$ and $\mathbf{3}-\mathbf{I}$ involves two polymetallic units forming alternating cationic and anionic hexagonal layers with an unusual sequence of packing along the $c$ axis (Fig. S3). The hexagonal layers of $\left\{\mathrm{Al}_{13}\right\}^{7+}$ are aligned along the sixfold helicoidal axis $\left(6_{2}\right)$, and the hexagonal layers of molybdenum clusters adopt the stacking sequence $A^{\prime} A^{\prime \prime} A^{\prime \prime \prime} A^{\prime}$. Therefore, the combined stacking sequence is thus $A^{\prime} B A^{\prime \prime} B A^{\prime \prime \prime} B A^{\prime} B$, where the shortest distance between two neighbouring complementary clusters is $5.5 \AA$, highlighting the key role of long-range Coulomb forces as structure directing motif assembly. Each $\left\{\mathrm{Al}_{13}\right\}^{7+}$ unit is coordinated by four $\left\{\left[\mathrm{Mo}_{6} \mathrm{X}_{8}^{\mathrm{i}} \mathrm{Cl}_{6}^{\mathrm{a}}\right] @ 2 \mathrm{CD}\right\}^{2-}$ adducts in form of disorder tetrahedron. Interestingly, the host-guest conformation of $\left\{\left[\mathrm{Mo}_{6} \mathrm{X}_{8}^{\mathrm{i}} \mathrm{Cl}_{6}^{\mathrm{a}}{ }_{6} @ 2 \mathrm{CD}\right\}^{2-}\right.$ corresponds to those observed in aqueous solution, meaning that iodine and bromine derivatives adopt the $\alpha$ - and $\beta$-isomer, respectively (Fig. 5b, 5c, and S5). The $\left\{\left[\mathrm{Mo}_{6} \mathrm{X}_{8}^{\mathrm{i}} \mathrm{Cl}_{6}^{\mathrm{a}}\right] @ 2 \mathrm{CD}\right\}^{2-}$ adducts and $\left\{\mathrm{Al}_{13}\right\}^{7+}$ entities interact through hydrogen-bonds between hydroxo groups of $\mathrm{CD}$ and aqua or hydroxo groups of $\left\{\mathrm{Al}_{13}\right\}^{7+}$ with $\mathrm{O} \bullet \bullet \mathrm{O}$ distances in the range 2.66-2.73 $\AA$ (Fig. 5a). These weakly attractive forces mediated by chiral macrocyclic units generate giant right-handed double helix with a diameter about $35 \AA$ and a rise per turn about $115.6 \AA$ ( 2 times the $c$ parameter; Fig. $5 a)$. To the best of our knowledge, double helices without covalent backbone are quite rare since only one example, resulting from self-assembly of hybrid polyoxometalate into left-handed double helix, has been reported so far. ${ }^{83}$ Another striking feature of the helical arrangement built on $\left\{\left[\mathrm{Mo}_{6} \mathrm{X}_{8}^{\mathrm{i}} \mathrm{Cl}_{6}^{\mathrm{a}}{ }_{6} @ 2 \mathrm{CD}\right\}^{2-}\right.$ is that the two helices does not interact directly through hydrogen bonds as usually observed in DNAlike structures. In fact, supramolecular bridging $\left\{\mathrm{Al}_{13}\right\}^{7+}$ species allow the cohesion of two sequences through a network of short range interactions (e.g. hydrogen bonds) supported by long range Coulomb forces between cationic and anionic building clusters. In addition to the ionic polymetallic aggregates, four chlorine anions are localized by the analysis of the diffraction data, they are around the $\left\{\mathrm{Al}_{13}\right\}^{7+}$ unit. One remaining $\mathrm{Cl}^{-}$anion per $\left\{\mathrm{Al}_{13}\right\}^{7+}$ unit is required for charge balancing. It has been localized in the large structural voids (41\% of cell volume; Fig S10) containing disordered water molecules. Interestingly, the presence of large voids as well as inert aluminium based polycations gives rise to a dilution of the luminophores within the structural arrangement. This crystalline phase is 6.5 times less dense in luminophores by comparison to $\mathrm{TBA}_{2}\left[\mathrm{Mo}_{6} \mathrm{X}_{8}^{\mathrm{i}} \mathrm{Cl}_{6}^{\mathrm{a}}\right]$.

Table 1: Comparison of the structural and photoluminescence properties of the solids $\mathrm{TBA}_{2}\left[\left.\mathrm{Mo}_{6}\right|_{8} ^{\mathrm{i}} \mathrm{Cl}_{6}^{\mathrm{a}}{ }_{6}\right], \mathbf{1}-\mathbf{I}, \mathbf{2}-\mathrm{I}$ and 3-I. The solid state emission and absolute quantum yields have been determined at $22^{\circ} \mathrm{C}$ in $\mathrm{N}_{2}$ atmosphere. Lifetime measurements have been measured at $22^{\circ} \mathrm{C}$ in air.

\begin{tabular}{|c|c|c|c|c|c|c|c|c|}
\cline { 2 - 8 } \multicolumn{1}{c|}{} & \multicolumn{9}{|c|}{ Photoluminescence properties } & \multicolumn{3}{|c|}{ Structural properties } \\
\hline Compounds & $\begin{array}{c}\lambda_{\max }{ }^{[\mathrm{a}]} \\
(\mathrm{nm})\end{array}$ & $\begin{array}{c}\Phi^{[\mathrm{a}]} \\
(\%)\end{array}$ & $\begin{array}{c}\tau_{1}{ }^{[\mathrm{b}]} \\
(\mu \mathrm{s})\end{array}$ & $\begin{array}{c}\tau_{2}{ }^{[\mathrm{b}]} \\
(\mu \mathrm{s})\end{array}$ & $\begin{array}{c}\tau_{0}{ }^{[\mathrm{e}]} \\
(\mu \mathrm{s})\end{array}$ & $\begin{array}{c}\text { Unit cell } \\
\left(\AA^{3}\right)\end{array}$ & $\begin{array}{c}\text { Voids } \\
{[\mathrm{c}]}\end{array}(\%)$ & $\begin{array}{c}\text { Clusters } \\
\text { per unit } \\
\text { cell }\end{array}$ \\
\hline $\begin{array}{c}\mathrm{TBA}_{2}\left[\mathrm{Mo}_{6} \mathrm{X}_{8}^{\mathrm{i}} \mathrm{Cl}_{6}^{\mathrm{a}}\right] \\
{[\mathrm{d}]}\end{array}$ & 710 & 56 & $\begin{array}{c}163 \\
(100 \%)\end{array}$ & - & 163 & 3003 & $<2$ & 2 \\
\hline $\mathbf{1 - I}$ & 690 & 40 & $\begin{array}{c}133 \\
(100 \%)\end{array}$ & - & 133 & 9038 & 14 & 2 \\
\hline $2-1$ & 690 & 33 & $\begin{array}{c}117 \mu \mathrm{s} \\
(86 \%)\end{array}$ & $\begin{array}{c}27 \mu \mathrm{s} \\
(14 \%)\end{array}$ & 114 & 31944 & 46 & 4 \\
\hline $3-1$ & 690 & 26 & $\begin{array}{c}126 \mu \mathrm{s} \\
(36 \%)\end{array}$ & $\begin{array}{c}81 \mu \mathrm{s} \\
(64 \%)\end{array}$ & 102 & 19465 & 41 & 2 \\
\hline
\end{tabular}

[a] : $\lambda_{\text {ex }}=365 \mathrm{~nm} ;[\mathrm{b}]: \lambda_{\text {ex }}=375 \mathrm{~nm}$; [c] percentage of free volume per unit cell (calculated using PLATON); [d] : Structural parameters have been determined using reported crystal structure. ${ }^{70}[\mathrm{e}] \tau_{0}=\left(\mathrm{A}_{1} \cdot \tau_{1}{ }^{2}+\mathrm{A}_{2} \cdot \tau_{2}{ }^{2}\right) /\left(\mathrm{A}_{1} \cdot \tau_{1}+\mathrm{A}_{2} \cdot \tau_{2}\right)$

Steady state and time resolved photoluminescence properties were investigated on supramolecular solids built from $\left\{\left[\mathrm{Mo}_{6} \mathrm{I}_{8}^{\mathrm{i}} \mathrm{Cl}{ }_{6}^{\mathrm{a}}\right] @ 2 \mathrm{CD}\right\}^{2-}$, and on $\mathrm{TBA}_{2}\left[\mathrm{Mo}_{6} \mathrm{I}_{8}^{\mathrm{i}} \mathrm{Cl}{ }_{6}^{\mathrm{a}}\right]$ acting as reference. We choose to study exclusively the compounds containing iodide derivative since this cluster show the best phosphorescent performances compared to the bromide 
analogue. The emission maximum wavelengths $\left(\lambda_{\text {max }}\right)$, absolute quantum yields $(\phi)$ and lifetimes $(\tau)$ are provided in Table 1. As the compounds $\mathbf{1 - I}, \mathbf{2}-\mathbf{I}$ and $\mathbf{3}-\mathbf{I}$ are built on the same inclusion complex, similar photoluminescence properties could be expected. In our experimental conditions, these solids exhibit similar $\lambda_{\max }$ than $\left\{\left[\mathrm{Mo}_{6} \mathrm{I}_{8}^{\mathrm{i}} \mathrm{Cl}_{6}^{\mathrm{a}}{ }_{6}\right] @ 2 \mathrm{CD}\right\}^{2-}$ in aqueous solution (Fig. S21), however $\phi$ and $\tau_{0}$ values vary concomitantly from one supramolecular solid to another.

Quantum yield measurements realized under $\mathrm{N}_{2}$ show that the use of $\left\{\left[\mathrm{Mo}_{6} \mathrm{I}_{8}^{\mathrm{i}} \mathrm{Cl}_{6}^{\mathrm{a}}\right] @ 2 \mathrm{CD}\right\}^{2-}$ as building block of supramolecular solids promote the formation of highly luminescent compounds characterized by high absolute quantum yield values ranging from 26 to $40 \%$. The lowering of the $\phi$ in compounds 1-I, 2-I and 3-I can be due to residual oxygen molecules trapped within the structure due to the presence of voids. Time resolved luminescence data recorded under air atmosphere were fitted with a mono-exponential or biexponential function, revealing that lifetimes are in the range of several microseconds as usually observed for $\left[\mathrm{Mo}_{6}{ }_{8}^{\mathrm{i}} \mathrm{Cl}_{6}^{\mathrm{a}}\right]^{2-}$ in solution. The presence of a second and shorter lifetime component in the emission decays is sometimes observed when cluster based materials present $\mathrm{O}_{2}$ permeability. ${ }^{84}$ Herein, double exponential emission behaviour is observed exclusively on solids exhibiting large voids (higher than $40 \%$ ) which favour probably the gas permeability. These photoluminescence investigations demonstrate that cyclodextrin driven self-assembling concept is an efficient way to integrate $\left[\mathrm{Mo}_{6} \mathrm{I}_{8}^{\mathrm{i}} \mathrm{Cl}_{6}^{\mathrm{a}}\right]^{2-}$ into hosting hybrid matrices with a minimal alteration of the luminescent properties of luminophores.

\section{Conclusions}

In conclusion, we reported the host-guest stabilization of molybdenum clusters in aqueous solution through their close embedding into $\gamma$-cyclodextrins acting as a protective shell against the hydrolytic attacks. Solution studies reveal that $C D$ strongly binds the clusters, forming robust luminescent and redox-active inclusion complexes. Then, we pioneer a novel concept to tailor functional materials using preformed metal aggregates acting as complementary building blocks. Their programmed association within a 3D organization is insured by a natural polysaccharide ( $\gamma$-cyclodextrin), and the resulting arrangement mimicks the crystalline arrangement found in oxide solid-state chemistry. Two types of super-tetrahedrons of $\left\{\mathrm{Al}_{13}\right\} \mathrm{Cl}_{4}$ and $\left\{\mathrm{Mo}_{6}\right\} \mathrm{Cl}_{4}$ share apices to form a tailor-made architecture related to that of the lithium alumino silicate $\mathrm{LiAlSiO}_{4}$. Encapsulation of luminophores in an inert matrix to form solid-state compounds with tuned luminescent properties reminds the doping of solid-state oxides like aluminates or alumina-silicates by rare earths. All these results together suggest that using cyclodextrin driven assembling offers new horizons in materials science, not only for manipulation of bottom-up construction of advanced materials resulting from precise self-assembly of preformed clusters but also to maintain the integrity of luminescent properties within a inorganic hosting matrix. Taking benefit of the extensive library of metallic aggregates, cyclodextrin driven selfassembling concept offers broad perspectives in the field of crystal engineering and more generally in material science. Indeed, considering the design of materials with several desired properties (optical, catalytic, magnetic, etc.), building blocks that will carry those specific properties could be selected among numerous types of soluble metallic aggregates such as transition metal atom clusters, polyoxometalates, $\mathrm{Al}^{3+}$ based polycations, polynuclear single molecule magnets $\left(\mathrm{Mn}_{12}\right.$, $\mathrm{Fe}_{8 . .}$ ) or polynuclear $\mathrm{d}^{10}$ complexes.

\section{Conflicts of interest}

There are no conflicts to declare.

\section{Acknowledgements}

Authors gratefully acknowledge financial support from IRPCLUSPOM 2019-2023, CNRS MOMENTUM and LabEx CHARMMMAT (ANR-11-LBX-0039-grant). This work was also supported by i) University of Versailles Saint Quentin, ii) University of Rennes and iii) CNRS. NIIC team acknowledges Russian Science Foundation [grant no. 19-73-20109] and Ministry of science and higher education of RF.

\section{References}

1 D. A. Tomalia and S. N. Khanna, Chem. Rev., 2016, 116, 27052774.

2 D.-L. Long, R. Tsunashima and L. Cronin, Angew. Chem. Int. Ed., 2010, 49, 1736-1758.

3 R. J. Wilson, N. Lichtenberger, B. Weinert and S. Dehnen, Chem. Rev., 2019, 119, 8506-8554.

4 Z. L. Mensinger, W. Wang, D. A. Keszler and D. W. Johnson, Chem. Soc. Rev., 2012, 41, 1019-1030.

5 A. Misra, K. Kozma, C. Streb and M. Nyman, Angew. Chem. Int. Ed., 2020, 59, 596-612.

6 A. Turkiewicz, D. W. Paley, T. Besara, G. Elbaz, A. Pinkard, T. Siegrist and X. Roy, J. Am. Chem. Soc., 2014, 136, 15873-15876.

7 H. Liu, C.-H. Hsu, Z. Lin, W. Shan, J. Wang, J. Jiang, M. Huang, B. Lotz, X. Yu, W.-B. Zhang, K. Yue and S. Z. D. Cheng, J. Am. Chem. Soc., 2014, 136, 10691-10699.

8 Uchida, Polyoxometalate-Based Assemblies and Functional Materials, ed. Y.-F. Song, Springer International Publishing, Cham, 2018, 65-87.

9 M. A. Moussawi, N. Leclerc-Laronze, S. Floquet, P. A. Abramov, M. N. Sokolov, S. Cordier, A. Ponchel, E. Monflier, H. Bricout, D. Landy, M. Haouas, J. Marrot and E. Cadot, J. Am. Chem. Soc., 2017, 139, 12793-12803.

10 W. H. Casey, Chem. Rev., 2006, 106, 1-16.

11 L. Rozes and C. Sanchez, Chem. Soc. Rev., 2011, 40, 1006-1030.

12 D. N. Woodruff, R. E. P. Winpenny and R. A. Layfield, Chem. Rev., 2013, 113, 5110-5148.

13 V. W.-W. Yam and K. K.-W. Lo, Chem. Soc. Rev., 1999, 28, 323334.

14 Single-Molecule Magnets: Molecular Architectures and Building Blocks for Spintronics, ed. M. Holynska, Wiley-VCH.

15 F. Clabau, X. Rocquefelte, S. Jobic, P. Deniard, M.-H. Whangbo, A. Garcia and T. Le Mercier, Chem. Mater., 2005, 17, 3904-3912. 
16 A. Brenier, G. Jia and C. Tu, J. Phys.: Condens. Matter, 2004, 16, 9103-9108.

17 M. Machida, S. Murakami, T. Kijima, S. Matsushima and M. Arai, J. Phys. Chem. B, 2001, 105, 3289-3294.

18 K. P. F. Siqueira, P. P. Lima, R. A. S. Ferreira, L. D. Carlos, E. M. Bittar, F. M. Matinaga, R. Paniago, K. Krambrock, R. L. Moreira and A. Dias, J. Phys. Chem. C, 2015, 119, 17825-17835.

19 D. Jia, X. J. Wang, W. Jia and W. M. Yen, Journal of Applied Physics, 2002, 93, 148-152.

20 T. Jüstel, H. Bechtel, W. Mayr and D. U. Wiechert, J. Lumin., 2003, 104, 137-143.

21 T. Aitasalo, P. Dereń, J. Hölsä, H. Jungner, J.-C. Krupa, M. Lastusaari, J. Legendziewicz, J. Niittykoski and W. Stręk, J. Solid State Chem., 2003, 171, 114-122.

22 R. Sakai, T. Katsumata, S. Komuro and T. Morikawa, J. Lumin., 1999, 85, 149-154.

23 Y. Sato, H. Kato, M. Kobayashi, T. Masaki, D.-H. Yoon and M. Kakihana, Angew. Chem. Int. Ed., 2014, 53, 7756-7759.

24 J. S. Kim, P. E. Jeon, J. C. Choi and H. L. Park, Solid State Commun., 2005, 133, 187-190.

25 J. K. Park, C. H. Kim, S. H. Park, H. D. Park and S. Y. Choi, Appl. Phys. Lett., 2004, 84, 1647-1649.

26 M. Yamaga, Y. Tanii, N. Kodama, T. Takahashi and M. Honda, Phys. Rev. B, 2002, 65, 235108.

27 I. P. Sahu, D. P. Bisen, N. Brahme and R. K. Tamrakar, J. Mater. Sci.: Mater. Electron., 2015, 26, 10075-10086.

28 Y. Wang, Z. Wang, P. Zhang, Z. Hong, X. Fan and G. Qian, Mater. Lett., 2004, 58, 3308-3311.

29 X.-J. Wang, D. Jia and W. M. Yen, J. Lumin., 2003, 102-103, 3437.

30 J. H. Golden, H. Deng, F. J. DiSalvoa, J. M. J. Fréchet and P. M. Thompson, Science, 1995, 268, 1463-1466.

31 M. Prévôt, M. Amela-Cortes, S. K. Manna, R. Lefort, S. Cordier, H. Folliot, L. Dupont and Y. Molard, Adv. Funct. Mater., 2015, 25, 4966-4975.

32 Y. Molard, Acc. Chem. Res., 2016, 49, 1514-1523.

33 K. Guy, P. Ehni, S. Paofai, R. Forschner, C. Roiland, M. Amela-Cortes, S. Cordier, S. Laschat and Y. Molard, Angew. Chem. Int. Ed., 2018, 57, 11692-11696.

34 S. Khlifi, J. Bigeon, M. Amela-Cortes, N. Dumait, G. Loas, S. Cordier and Y. Molard, ACS Appl. Mater. Interfaces, 2020, 12, 14400-14407.

35 S. Khlifi, N. Fournier Le Ray, S. Paofai, M. Amela-Cortes, H. Akdas-Kiliç, G. Taupier, S. Derien, S. Cordier, M. Achard and Y. Molard, Mater. Today, , DOI:10.1016/j.mattod.2019.12.002.

36 M. Kepenekian, Y. Molard, K. Costuas, P. Lemoine, R. Gautier, S. A. Girard, B. Fabre, P. Turban and S. Cordier, Mater. Horiz., 2019, 6, 1828-1833.

37 S. Ababou-Girard, S. Cordier, B. Fabre, Y. Molard and C. Perrin, ChemPhysChem, 2007, 8, 2086-2090.

38 Y. Molard, F. Dorson, K. A. Brylev, M. A. Shestopalov, Y. Le Gal, S. Cordier, Y. V. Mironov, N. Kitamura and C. Perrin, Chem. Eur. J., 2010, 16, 5613-5619.

39 M. Amela-Cortes, A. Garreau, S. Cordier, E. Faulques, J.-L. Duvail and Y. Molard, J. Mater. Chem. C, 2014, 2, 1545-1552.

40 F. Sciortino, J. Cuny, F. Grasset, C. Lagrost, P. Lemoine, A. Moréac, Y. Molard, T. Takei, S. Cordier, S. Chevance and F. Gauffre, Chem. Commun., 2018, 54, 13387-13390.

41 A. O. Solovieva, Y. A. Vorotnikov, K. E. Trifonova, O. A. Efremova, A. A. Krasilnikova, K. A. Brylev, E. V. Vorontsova, P. A. Avrorov, L. V. Shestopalova, A. F. Poveshchenko, Y. V. Mironov and M. A. Shestopalov, J. Mater. Chem. B, 2016, 4, 4839-4846.
42 N. Brandhonneur, T. Hatahet, M. Amela-Cortes, Y. Molard, S. Cordier and G. Dollo, Eur. J. Pharm. Biopharm, 2018, 125, 95105.

43 F. Grasset, F. Dorson, S. Cordier, Y. Molard, C. Perrin, A.-M. Marie, T. Sasaki, H. Haneda, Y. Bando and M. Mortier, Adv. Mater., 2008, 20, 143-148.

44 T. Aubert, F. Cabello-Hurtado, M.-A. Esnault, C. Neaime, D. Lebret-Chauvel, S. Jeanne, P. Pellen, C. Roiland, L. Le Polles, N. Saito, K. Kimoto, H. Haneda, N. Ohashi, F. Grasset and S. Cordier, J. Phys. Chem. C, 2013, 117, 20154-20163.

45 A. Gandubert, M. Amela-Cortes, S. K. Nayak, C. Vicent, C. Mériadec, F. Artzner, S. Cordier and Y. Molard, J. Mater. Chem. C, 2018, 6, 2556-2564.

46 Y. Molard, F. Dorson, V. Cîrcu, T. Roisnel, F. Artzner and S. Cordier, Angew. Chem. Int. Ed., 2010, 49, 3351-3355.

47 K. A. Brylev, N. G. Naumov, A. V. Virovets, S.-J. Kim and V. E. Fedorov, J. Clust. Sci., 2009, 20, 165-176.

48 G. Daigre, P. Lemoine, T. D. Pham, V. Demange, R. Gautier, N. G. Naumov, A. Ledneva, M. Amela-Cortes, N. Dumait, N. Audebrand and S. Cordier, CrystEngComm, 2018, 20, 33963408.

49 M. A. Moussawi, M. Haouas, S. Floquet, W. E. Shepard, P. A. Abramov, M. N. Sokolov, V. P. Fedin, S. Cordier, A. Ponchel, E. Monflier, J. Marrot and E. Cadot, J. Am. Chem. Soc., 2017, 139, 14376-14379.

50 Y. Wu, R. Shi, Y.-L. Wu, J. M. Holcroft, Z. Liu, M. Frasconi, M. R. Wasielewski, H. Li and J. F. Stoddart, J. Am. Chem. Soc., 2015, 137, 4111-4118.

51 P. Yang, W. Zhao, A. Shkurenko, Y. Belmabkhout, M. Eddaoudi, X. Dong, H. N. Alshareef and N. M. Khashab, J. Am. Chem. Soc., 2019, 141, 1847-1851.

52 A. A. Ivanov, C. Falaise, P. A. Abramov, M. A. Shestopalov, K. Kirakci, K. Lang, M. A. Moussawi, M. N. Sokolov, N. G. Naumov, S. Floquet, D. Landy, M. Haouas, K. A. Brylev, Y. V. Mironov, Y. Molard, S. Cordier and E. Cadot, Chem. Eur. J., 2018, 24, 1346713478.

53 A. A. Ivanov, C. Falaise, K. Laouer, F. Hache, P. Changenet, Y. V. Mironov, D. Landy, Y. Molard, S. Cordier, M. A. Shestopalov, M. Haouas and E. Cadot, Inorg. Chem., 2019, 58, 13184-13194.

54 K. I. Assaf, M. S. Ural, F. Pan, T. Georgiev, S. Simova, K. Rissanen, D. Gabel and W. M. Nau, Angew. Chem. Int. Ed., 2015, 54, 68526856.

55 K. I. Assaf, O. Suckova, N. Al Danaf, V. von Glasenapp, D. Gabel and W. M. Nau, Org. Lett., 2016, 18, 932-935.

56 P. A. Abramov, A. A. Ivanov, M. A. Shestopalov, M. A. Moussawi, E. Cadot, S. Floquet, M. Haouas and M. N. Sokolov, J. Clust. Sci., 2018, 29, 9-13.

57 S. Akagi, S. Fujii and N. Kitamura, Dalton Trans., 2018, 47, 11311139.

58 J. C. Sheldon, J. Chem. Soc., 1962, 410-415.

59 G. Daigre, J. Cuny, P. Lemoine, M. Amela-Cortes, S. Paofai, N. Audebrand, A. Le Gal La Salle, E. Quarez, O. Joubert, N. G. Naumov and S. Cordier, Inorg. Chem., 2018, 57, 9814-9825.

60 C. Falaise, M. A. Moussawi, S. Floquet, P. A. Abramov, M. N. Sokolov, M. Haouas and E. Cadot, J. Am. Chem. Soc., 2018, 140, 11198-11201.

61 D. Fiedler, R. G. Bergman and K. N. Raymond, Angew. Chem. Int. Ed., 2006, 45, 745-748.

62 M. Ziegler, J. L. Brumaghim and K. N. Raymond, Angew. Chem. Int. Ed., 2000, 39, 4119-4121.

63 M. Yoshizawa, T. Kusukawa, M. Fujita, S. Sakamoto and K. Yamaguchi, J. Am. Chem. Soc., 2001, 123, 10454-10459. 
64 L.-X. Cai, S.-C. Li, D.-N. Yan, L.-P. Zhou, F. Guo and Q.-F. Sun, J. Am. Chem. Soc., 2018, 140, 4869-4876.

65 W. Xuan, A. J. Surman, Q. Zheng, D.-L. Long and L. Cronin, Angew. Chem. Int. Ed., 2016, 55, 12703-12707.

66 Crystallographic data for 1-Br: Monoclinic, $P 2_{1}, a=15.8501(17)$ $b=32.821(4) \quad c=17.405(2) \AA, \alpha=\gamma=90 \beta=93.734(4))^{\circ}, V=$ 9035.4(18) $\AA^{3}$. Depository number CSD-1987553. Crystallographic data for 1-I: Monoclinic, $P 2_{1}, a=15.8187(9)$ $b=32.856(2) \quad c=17.4013(11) \AA, \alpha=\gamma=90 \beta=93.728(2){ }^{\circ}, V=$ 9025.0(9) Å3. Depository number CSD-1987552.

67 Crystallographic data for 2-Br: Tetragonal, 1422, $a=b=23.715(2)$ $c=56.802(5) \AA, \alpha=\beta=\gamma=90^{\circ}, V=31945(7) \AA^{3}$. Depository number CSD-1987554. Crystallographic data for 2-I: Tetragonal, 1422, $a=b=23.7708(16) c=57.456(4) \AA, \alpha=\beta=\gamma=90^{\circ}, V=32465(5) \AA^{3}$. Depository number CSD-1987556.

68 Z. Liu, M. Frasconi, J. Lei, Z. J. Brown, Z. Zhu, D. Cao, J. lehl, G. Liu, A. C. Fahrenbach, Y. Y. Botros, O. K. Farha, J. T. Hupp, C. A. Mirkin and J. F. Stoddart, Nat Commun, 2013, 4, 1-9.

69 W. Preetz, D. Bublitz, H. G. V. Schnering and J. Saßmannshausen, Z. Anorg. Allg. Chem., 1994, 620, 234-246.

70 P. Brückner, W. Preetz and M. Pünjer, Z. Anorg. Allg. Chem., 1997, 623, 8-17.

71 K. I. Assaf and W. M. Nau, Angew. Chem. Int. Ed., 2018, 57, 13968-13981.

72 A. A. Ivanov, C. Falaise, D. Landy, M. Haouas, Y. V. Mironov, M. A. Shestopalov and E. Cadot, Chem. Commun., 2019, 55, 99519954.

73 N. A. Vorotnikova, Y. A. Vorotnikov, I. N. Novozhilov, M. M. Syrokvashin, V. A. Nadolinny, N. V. Kuratieva, D. M. Benoit, Y. V. Mironov, R. I. Walton, G. J. Clarkson, N. Kitamura, A. J. Sutherland, M. A. Shestopalov and O. A. Efremova, Inorg. Chem., 2018, 57, 811-820.

74 J. E. Geusic, H. M. Marcos and L. G. Van Uitert, Appl. Phys. Lett., 1964, 4, 182-184.

75 A. Ikesue, T. Kinoshita, K. Kamata and K. Yoshida, J. Am. Ceram. Soc., 1995, 78, 1033-1040.

76 G. Johansson, L.-O. Gullman, A. Kjekshus and R. Söderquist, Acta Chem. Scand., 1960, 14, 771-773.

77 L. Allouche, C. Gérardin, T. Loiseau, G. Férey and F. Taulelle, Angew. Chem. Int. Ed., 2000, 39, 511-514.

78 S. Abeysinghe, D. K. Unruh and T. Z. Forbes, Crystal Growth \& Design, 2012, 12, 2044-2051.

79 Crystallographic data for 3-Br: Hexagonal, $P 6_{2} 22, a=b=19.805(2)$ $c=57.843(7) \AA, \alpha=\beta=90 \gamma=120^{\circ}, V=19649(5) \AA^{3}$. Depository number CSD-1987555. Crystallographic data for 3-I: Hexagonal, $P 6_{2} 22, a=b=19.751(2) c=57.616(7) \AA, \alpha=\beta=90 \gamma=120^{\circ}, V=$ 19465(5) $\AA^{3}$. Depository number CSD-1987557.

80 H. Schulz and V. Tscherry, Acta Cryst B, 1972, 28, 2174-2177.

81 G. Férey, C. Serre, C. Mellot-Draznieks, F. Millange, S. Surblé, J. Dutour and I. Margiolaki, Angew. Chem. Int. Ed., 2004, 43, 6296-6301.

82 G. Férey, C. Mellot-Draznieks, C. Serre, F. Millange, J. Dutour, S. Surblé and I. Margiolaki, Science, 2005, 309, 2040-2042.

83 V. Kulikov, N. A. B. Johnson, A. J. Surman, M. Hutin, S. M. Kelly, M. Hezwani, D.-L. Long, G. Meyer and L. Cronin, Angew. Chem. Int. Ed., 2017, 56, 1141-1145.

84 M. Amela-Cortes, S. Paofai, S. Cordier, H. Folliot and Y. Molard, Chem. Commun., 2015, 51, 8177-8180. 